\title{
Strict Products Liability to the Bystander: A Study in Common Law Determinism
}

The law of products liability has come a long way since the days of Winterbottom $v$. Wright. ${ }^{1}$ The rule of that case was gradually eaten away by exceptions ${ }^{2}$ until it was swallowed up by the new rule in MacPherson v. Buick Motor Co. ${ }^{3}$ The citadel of privity ${ }^{4}$ was assaulted and finally toppled in Henningsen $v$. Bloomfield Motors, Inc. ${ }^{5}$ Old fictions ${ }^{8}$ gave way to new theory in Greenman v. Yuba Power Products, Inc. ${ }^{7}$ These developments were codified and restated, ${ }^{8}$ narrated, analyzed, and commented upon in a still growing body of literature. ${ }^{9}$

After Henningsen and Greenman, the case law permitted any user or consumer who was injured by a defective product to recover directly from the manufacturer, even in the absence of negligence, on theories

110 M. \& W. 109, 152 Eng. Rep. 402 (Ex. 1842) (recovery in negligence denied to an injured coachman in action against the once removed supplier of a defective coach which broke down). In the prophetic words of Lord Abinger,

There is no privity of contract between these parties; and if the plaintiff can sue, every passenger, or even any person passing along the road, who was injured by the upsetting of the coach, might bring a similar action. Unless we confine the operation of such contracts as this to the parties that entered into them, the most absurd and outrageous consequences, to which I see no limit, would ensue.

Id. at 114, 152 Eng. Rep. at 405.

2 These are summarized in Huset v. Case Threshing Co., 120 F. 865 (8th Gir. 1903). The expansion of the "dangerous instrumentality" exception is analyzed in E. LEVI, AN INTRODUCTION TO LEGAL REASONING 9-27 (1948).

3217 N.Y. 382, 111 N.E. 1050 (1916) (recovery in negligence allowed to the injured ultimate purchaser against the manufacturer of an automobile which collapsed due to a defective wheel, opinion by Cardozo, J.).

4 See Prosser, The Assault upon the Citadel (Strict Liability to the Consumer), 69 YALE L.J. 1099 (1960). The phrase comes from Cardozo's oft-quoted observation, "The assault upon the citadel of privity is proceeding in these days apace." Ultramares Corp. v. Touche, 255 N.Y. 170, 180, 174 N.E. 441, 445 (1931).

532 N.J. 358, 161 A.2d 69 (1960) (recovery in implied warranty allowed to the injured user against the manufacturer of an automobile with a defective steering mechanism which caused it to go out of control).

6 For the definitive list of 29 fictions, see Gillam, Products Liability in a Nutshell, 37 ORE. L. REv. 119, 153-55 (1957).

759 Cal. 2d 57, 377 P.2d 897, 27 Cal. Rptr. 697 (1962) (recovery in strict tort liability allowed to the injured user against the manufacturer of a defective lathe which threw off a piece of wood, opinion by Traynor, C.J.).

8 UNIFORM COMMERCLAL CODE \$ 2-818; Restatement (SECOND) OF TORTS \$ 402A.

- The major recent articles are included in the bibliography in C.O. Gregory \& $H$. RAIVEN, JR., CASES AND MATERIAIS ON TORTS liii-lv (2d ed. 1969). For a more exhaustive if now dated bibliography, see Gillam, supra note 6, at 128 n.39. 
of implied warranty and strict tort liability. ${ }^{10}$ Courts and commentators speculated as to whether these theories of recovery would be extended beyond the user or consumer to a person having absolutely no connection with the product save that it injured him-the innocent bystander. The general feeling was that such an extension would mark the complete abolition of long standing doctrine limiting recovery to those somehow "in privity" with the manufacturer, and that-if it were to come at all-it would be celebrated with an opinion comparable to MacPherson or Greenman. ${ }^{11}$

At present, courts in at least eight states have allowed the bystander a cause of action in strict products liability, ${ }^{12}$ and several others have al-

10 See 1 CCH Prod. LIAB. REP. I 4060; Comment, Cave Adstantem: Bystander Recovery in Products Liability Cases, 2 CreIGHron L. Rev. 295 (1969).

11 In 1964, no case had yet held for the bystander, Note, Strict Products Liability and the Bystander, 64 CoLuM. L. Rev. 916, 918 \& n.11 (1964), and several had held against, id. at 916 n.3. Among commentators, Harper and James were the only major advocates of bystander recovery. See text at note 36 infra. See also P. KeEton \& M. Shapo, Products and the Consumer: Defective and Dangerous Products 570 (1970). Prosser, the champion of strict liability to the user or consumer, was cautious, giving bystander recovery only qualified approval in principle and indicating no conviction that such recovery would be adopted:

Unquestionably the "emotional drive" and the public demand that has sprung

from it have centered in the consumer. There may be no very logical reason why

the seller should not assume strict responsibility to such casual bystanders,

other than the fact that they are not the people whom he seeks to reach with

his goods, and so they do not have the same reason to rely upon any implied

assurance of safety. It may, however, be expected that any extension to the non-

consumer will be slow; and it may perhaps never come.

Prosser, supra note 4, at 1142. Compare W. Prosser, HandBook of the LAW of Torts § 97, at 683 (1964 ed.) [hereinafter cited as Prosser]; Prosser, The Fall of the Citadel (Strict Liability to the Consumer), 50 MiNN. L. Rev. 791, 819-20 (1966); and text at note 32 infra.

A major student note remarked that, "if the assault [upon the citadel of privity] should prove completely successful, the last gasp will come when recovery is allowed to persons who have no connection with a product except an injury caused them by its defective condition." Note, supra, at 916. The note analyzed the possibilities for bystander recovery under various legal theories in the context of the continuing erosion of the privity requirement and concluded that strict tort liability would be the most appropriate route. Id. at 936-37.

12 Wasik v. Borg, 423 F.2d 44 (2d Cir. 1970) (anticipating Vermont law); Sills v. Massey-Ferguson, Inc., 296 F. Supp. 776 (N.D. Ind. 1969) (anticipating Indiana law); Caruth v. Mariani, 11 Ariz. App. 188, 463 P.2d 83 (1970); Elmore v. American Motors Corp., 70 Cal. 2d 578, 451 P.2d 84, 75 Cal. Rptr. 652 (1969); Mitchell v. Miller, 26 Conn. Supp. 142, 214 A.2d 694 (1965); Toombs v. Fort Pierce Gas Co., 208 So. 2d 615 (Fla. 1968); Piercefield v. Remington Arms Co., 375 Mich. 85, 133 N.W.2d 129 (1965); Darryl v. Ford Motor Co., 440 S.W.2d 630 (Tex. 1969).

Since the inception of bystander recovery at least one student note has dealt with the general topic analytically and in some depth. Comment, supra note 10, examined the difficulties of bystander recovery in implied warranty as compared with strict tort liability. Various bystander cases have been noted in 19 AM. U.L. REv. 263 (1970); 15 AM. U.L. REv. 150 (1965); 22 BAYLOR L. REv. 152 (1970); 15 DRAKE L. REV. 137 (1965); 38 FordhaM L. REv. 579 (1970); 7 Houston L. Rev. 144 (1969); 25 MD. L. Rev. 267 (1965); 
lowed recovery to persons who could be categorized as bystanders. ${ }^{13}$ Yet the opinions making the extension to the bystander were mundane and uninteresting; most did no more than observe that there was no reason to distinguish the bystander from the user or consumer. Moreover, the decisions were uneventful in the sense that none even pretended to have changed the law dramatically; surely none will ever rival MacPherson or Greenman.

This comment explains the discrepancy between expectation and performance by analyzing the legal framework and policy considerations underlying the extension of strict products liability to the bystander. It concludes that the courts allowed bystander recovery so casually because it was impossible to withhold it. Strict tort liability, which was adopted to remedy the difficulties of user or consumer recovery in implied warranty, simultaneously eliminated any conceptual limitation on the class of plaintiffs who might recover. Bystander recovery appears to have been compelled for policy reasons as well, since the economic theories offered in support of strict products liability to the user or consumer apply with equal or greater force to the bystander. Finally, the comment calls attention to the apparent new anomaly that allows recovery to persons beyond the chain of distribution of defective products while imposing the more burdensome requirement of proof of negligence upon persons injured by imperfectly performed services, concluding however that the distinction has some validity.

\section{Legal Framework}

\section{A. From Warranty to Tort to the Bystander}

At early common law, the warranty action lay in tort. ${ }^{14}$ Later it became associated with the law of contracts and sales, and its growth was

42 N.D.L. Rev. 53 (1965); 47 TEXAs L. Rev. 1462 (1969); 23 U. MramI L. REv. 266 (1968); 9 WAsheruRN L.J. 483 (1970); 41 WAsh. L. Rev. 161 (1965).

Recent cases expressly refusing the bystander a cause of action include Mull v. Ford Motor Co., 368 F.2d 713 (2d Cir. 1966) (construing New York law); Davidson v. Leadingham, 294 F. Supp. 155 (E.D. Ky. 1968) (construing Kentucky law); Kuschy v. Norris, 25 Conn. Supp. 383, 206 A.2d 275 (1964); Brown v. Hall, 221 So. 2d 454 (Fla. App. 1969); Hahn v. Ford Motor Co., 256 Iowa 27, 126 N.W.2d 350 (1964); Berzon v. Don Allen Motors, Inc., 23 App. Div. 2d 530, 256 N.Y.S.2d 643 (1965). It is instructive to note that the courts which held in favor of the bystander made little mention of these unfavorable opinions. 13 Speed Fasteners, Inc. v. Newsom, 382 F.2d 395 (10th Cir. 1967) (construing Oklahoma law); Klimas v. Int'l Tel. \& Tel. Corp., 297 F. Supp. 937 (D.R.I. 1969) (construing Rhode Island law); Pike v. Frank G. Hough Co., 2 Cal. 3d 465, 467 P.2d 229, 85 Cal. Rptr. 629 (1970); Johnson v. Standard Brands Paint Co., 274 Cal. App. 2d 331, 90 Cal. Rptr. 194 (1969); Connolly v. Hagi, 24 Conn. Supp. 198, 188 A.2d 884 (1963); Ford Motor Co. v. Cockrell, 211 So. 2d 833 (Miss. 1968); Lonzrick v. Republic Steel Corp., 6 Ohio St. 2d 227, 218 N.E.2d 185 (1966).

14 Ames, History of Assumpsit, 2 HARv. L. REv. 1, 8 (1888). 
fashioned by considerations relating to the commercial relationship between buyer and seller. During this period the courts carefully protected sellers from suits by buyers and others. ${ }^{15}$ By the late nineteenth century, this trend had run its course and the law began to respond to a new and different consideration-the problem of injuries caused by defective products. ${ }^{16}$ The demands of non-buyers as well as buyers to be compensated for such injuries led the courts to reassess the privity requirement of the implied warranty action, which limited recovery to claims brought by the initial buyer against his immediate seller. ${ }^{17}$

To avoid the privity requirement, and thus to expand the liability of sellers beyond their immediate buyers, the courts engaged in a wide variety of fictions. ${ }^{18}$ To protect non-buyers under the contract of sale, courts further strained logic to surmount contractual disclaimers of liability and to avoid such commercial requirements as reliance and notice. ${ }^{19}$ Fictions and logic chopping prevailed. The Uniform Commercial Code allowed recovery on a third party beneficiary rationale as between the retailer and members of the immediate buyer's family, household, and guests, but only if they could reasonably be expected to be affected by the goods. ${ }^{20}$ Henningsen $v$. Bloomfield Motors, Inc. ${ }^{21}$ held

152 F. HARPER \& F. JAMES, THE LAW OF TORTS $\$ \S 28.15$, at 1570; 28.33 (1956) Thereinafter cited as Harper \& JAMES]; K. Lleweltyn, CAses and Materials on the LAw of Sales 204, $340-41$ (1930); Prosser \& 95, at 651; Prosser, The Implied Warranty of Merchantable Quality, 27 MrNN. L. REv. 117 (1943).

162 HARPER \& JAMES $\S 28.33$; Wade, Strict Tort Liability of Manufacturers, 19 Sw. L.J. 5, 6 (1965).

17 The erosion of the privity requirement at first took place only where a food product was involved, then widened to include products designed for intimate body use, products advertised by the manufacturer, and others. The story is told quite fully in Jaeger, Privity of Warranty: Has the Tocsin Sounded? 1 DuQUesne L. Rev. 1 (1963); Prosser, supra note 4. Other major chronicles include R. Dickerson, Products Liaburty aNd the FOOD CONSUMER 68-69, 93-110 (1951); 2 HARPER \& JAMES \$\$ 28.15-28.16; Gillam, supra note 6, at 147-59; Jeanblanc, Manufacturers' Liability to Persons Other Than Their Immediate Dendees, 24 VA. L. REv. 134, 146-58 (1937); Noel, Manufacturers of Products-The Drift Toward Strict Liability, 24 TENN. L. REv. 963, 985-1009 (1957). It is important to remember that the gradual abandonment of the privity requirement occurred simultaneously in two dimensions-the horizontal privity between the retailer and the nonpurchasing user or consumer, and the vertical privity between the manufacturer and the user or consumer who purchased from a retailer. In Henningsen v. Bloomfield Motors, Inc., 32 N.J. 358, 161 A.2d 69 (1960), neither aspect of privity was required. See text at note 21 infra.

18 Note 6 supra. See R. Dickerson, supra note 17, at 65-68, 95-107; Jaeger, supra note 17, at 56-63; Jeanblanc, supra note 17, at 149-55; Noel, supra note 17, at 985-88; Prosser, supra note 4, at $1124-26$.

19 These and other difficulties with the warranty approach are best stated in Prosser, supra note 4, at $1127-84$.

20 UnIform COMMERciat CODE § 2-318. All states except California and Louisiana and the District of Columbia have adopted this section or liberal variations. Arkansas, Maryland, Maine, and Vermont have extended its applicability to manufacturers. 1 CCH Prod. LIAB. REP. I 4110; Comment, supra note 10, at 324-25; and note 34 infra. 
the manufacturer liable to any user or consumer, but only if the injury was reasonably foreseeable. In extending the implied warranty so far beyond the scope of the contract, the courts were thus forced to adopt the tort concept of foreseeability to provide a limiting principle. By the 1960's the entire implied warranty development had produced an overly complex and analytically confusing legal framework. ${ }^{22}$ Rejection of this burdensome structure was inevitable, and the alternative to it was well known. ${ }^{23}$

Strict products liability in tort had been suggested by Traynor as early as 1944 in Escola v. Coca Cola Bottling Co. ${ }^{24}$ In Greenman v. Yuba Power Products, Inc.25 this cause of action was adopted as the law of California:

$[R]$ ules defining and governing warranties that were developed to meet the need of commercial transactions cannot properly be invoked to govern the manufacturer's liability to those injured by their defective products ....

[T] he liability is not one governed by the law of contract warranties but by the law of strict liability in tort. ${ }^{26}$

The victory of substance over form began to receive widespread judicial acceptance. In 1965, the American Law Institute adopted strict tort liability as part of the Second Restatement of Torts: "One who sells any product in a defective condition unreasonably dangerous to the user or consumer or to his property is subject to liability for physical harm thereby caused to the ultimate consumer or user, or to his property ...."27

But in sweeping away the conceptual complexity of implied warranty, strict tort liability also eliminated any conceptual reason to exclude bystander recovery. Greenman holds the manufacturer strictly

2132 N.J. 358, 161 A.2d 69 (1960). About half of the states have allowed user or consumer recovery in implied warranty. 1 CCH PROD. LIAB. REP. I 4060 and Comment, supra note 10 , at $324-25$.

22 Comment, supra note 10, at 304-05; see Cowan, Some Policy Bases of Products Liability, 17 Stan. L. Rev. 1077, 1084-86 (1965).

23 The shift from implied warranty to strict tort liability is traced in Kessler, Products Liability, 76 YALE L.J. 887, 891-911 (1967); McKean, Products Liability: Trends and Implications, 38 U. CHI. L. REv. 3, 14-20 (1970); Prosser, supra note 11, at 803-05; Wade, supra note 16, at 9-11.

2424 Cal. 2d 453, 461, 150 P.2d 436, 440 (1944).

2559 Cal. 2d 57, 377 P.2d 897, 27 Cal. Rptr. 697 (1962) (Traynor, G.J.).

26 Id. at 63, 377 P.2d at 901, 27 Cal. Rptr. at 701.

27 RESTATEMENT (SECOND) of ToRTs $\S 402$ A. Most states today allow user or consumer recovery in strict tort liability, following the Restatement or Greenman or both. 1 CCH PrOD. LIAB. REP. I 4060; Comment, supra note 10, at 324-25. 
liable when his defective product causes injury not merely to a user or consumer, but rather "to a human being." 28 The Restatement, while explicitly applicable only to users or consumers, includes a caveat stating that "[ $t$ ] he Institute expresses no opinion as to whether the rules stated in this Section may not apply ... to harm to persons other than users or consumers . . . ."29 A comment admits that "[ $t]$ here may be no essential reason why such plaintiffs should not be brought within the scope of protection afforded, other than that they do not have the same reasons for expecting such protection as the consumer who buys a marketed product," and that "the social pressure which has been largely responsible for the development of the rules has been a consumer's pressure, and there is not the same demand for the protection of casual strangers." ${ }^{30}$ The caveat articulates the essential point: once strict tort liability is accepted, bystander recovery is analytically fait accompli.

While strict tort liability inherently provided for bystander recovery, the bystander's claim on an implied warranty theory, as an analytic matter, was impossible to sustain. The implied warranty is conceptually related to the contract of sale; therefore the bystander is beyond its scope-he is not the buyer of the product, nor is he within its chain of distribution, nor has he relied on any warranty. ${ }^{31}$ As Prosser noted:

Bystanders, and other nonusers in the vicinity of the expected use, present a fundamental question of policy. If the philosophy of the strict liability is that all injured plaintiffs are to be compensated by holding the suppliers of products to strict [tort] liability for all the harm they do in the world, ... then there is no reason whatever to distinguish the pedestrian hit by an automobile with bad brakes from the injured driver of the car. [However, i]f the supplier is to be held liable [in implied warranty] because of his representation of safety in marketing the goods, then the pedestrian stands on quite a different footing. He is not the man the supplier has sought to reach, and no implied representation has been made to him that the product is safe for use; nor has he relied upon any assurance of safety whatever. ${ }^{32}$

2859 Cal. 2d at 62, 377 P.2d at 900, 27 Cal. Rptr. at 700 (emphasis added). See Note, supra note 11, at 936: "The bystander benefits from the explicit abandonment of a contractual basis because the privity requirement is abolished without an apologetic necessity for substituting some other relationship with the product or its buyer as a prerequisite to recovery."

29 RESTATEMENT (SECOND) OF TORTS $\S 402 A$, caveat.

30 Id., comment $o$.

31 " $[\mathrm{T}]$ he warranty device cannot be used to extend relief to one totally outside the chain of privity." Note, Manufacturers' Liability: MacPherson v. Buick Comes of Age, 4 U. CHr. L. REv. 461, 462 (1937).

32 Prosser, The Fall of the Citadel, supra note 11, at 819. 
Alternative theories to extend warranty protection to the bystander are equally unsupportable. The bystander cannot logically be considered a third party beneficiary, for the seller and buyer do not normally intend their contract to benefit any other party, either in fulfillment of a legal duty or in the form of a gift. ${ }^{33}$ Although the Uniform Commercial Code adopted this approach, it limited warranty protection to bystanders in the buyer's household, to whom intention of a gift is more credible. ${ }^{34}$ Finally, some courts have based user or consumer recovery upon the fiction that the warranty is imposed as a matter of public policy and runs with the chattel. ${ }^{35}$ As Harper and James recognized, this approach readily provides for bystander recovery:

Apparently recovery has not yet been allowed to [the by-
stander] on a warranty theory. But why not? Such injury is
often a perfectly foreseeable risk of the maker's enterprise, and
the considerations for imposing such risks on the maker with-
out regard to his fault do not stop with those who undertake
to use the chattel. Such a restriction is only the distorted
shadow of a vanishing privity which is itself a reflection of the
habit of viewing the problem as a commercial one between
traders, rather than as part of the accident problem.

The final phrase reveals the crucial point. Extending implied warranty theory to the bystander in this manner preserves nothing of the commercial aspects of implied warranty-only the label is retained. Since

33 Comment, supra note 12, at 297; Note, supra note 11, at 924-26.

34 See text at note 20 supra. The limitation to the household is qualified by a comment indicating that "the section is neutral and is not intended to restrict the developing case law on whether the seller's warranties, given to his buyer who resells, extend to other persons in the distributive chain." UNIFORM Commercial CODE § 2-318, comment 3. Harper and James have construed this comment as excluding bystanders and others not in the distributive chain. 2 HARPER \& JAMES $\$ 28.16$, at 1572 n.6. The better interpretation, however, is that the section is neutral as to horizontal as well as vertical extension, and that the negative pregnant is actually only a recognition of one dimension in which extension was already proceeding. This interpretation is supported by broad language elsewhere in the Code. Note, supra note 11 , at 928.

Two official alternatives to $\$ 2.318$ are more liberal regarding bystander recovery. Alternative $B$ extends the retailer's warranty to "any natural person who may reasonably be expected to use, consume or be affected by the goods and who is injured in person by breach of the warranty. ..." Alternative $C$ omits the words "natural" and "in person," allowing recovery to such parties as corporations and including such harms as property damage and economic loss. Colorado, Delaware, Kansas, Minnesota, South Carolina, South Dakota, Vermont, and Wyoming have adopted Alternative B. Alabama, Hawaii, North Dakota, and Rhode Island have adopted Alternative $C$. Texas and Virginia have adopted other variations. 1 CCH Prod. LIAB. REP. I 4110; Comment, supra note 10 , at $324-25$.

35 E.g., Henningsen v. Bloomfield Motors, Inc., 32 N.J. 358, 161 A.2d 69 (1960), which however expressly declined to offer a dictum on bystander recovery. Id. at 415, 161 A.2d at $100-01$.

362 HARper \& James \& 28.16, at 1572 n.6. 
the bystander's claim is based solely on the accident, it is really a tort claim; to allow the "implied warranty" action is really to allow an action in tort. And, as shown in the context of the development of strict tort liability, once liability is framed in tort, it is impossible to distinguish the bystander from the user or consumer.

\section{B. Bystander Recovery: A Foregone Conclusion}

In adopting strict tort liability the courts may well have failed to anticipate the bystander's compelling arguments for recovery. The Restatement harbored the illusion that liability might be limited to users or consumers, thus carrying over a residue of the old privity requirement. ${ }^{37}$ Prosser was undecided about resolution of the bystander's claim. $^{38}$ But it was soon discovered that, once strict tort liability was accepted, the claim of the bystander could not be denied. The bystander was, in the words of Greenman, a human being, and the tort concept extended liability to this broad class. Consequently, the courts called upon to allow the bystander's cause of action were able to do so without the flourish and fanfare reserved for solemn announcement of a new legal doctrine.

Piercefield v. Remington Arms Co., ${ }^{39}$ decided in 1965, was the first case expressly to allow a strict products liability cause of action to a bystander. A hunter injured by an exploding shotgun shell purchased and used by his brother sued the manufacturer and others. Although the complaint was framed in implied warranty, the Supreme Court of Michigan recognized that a decision for the bystander would create "a common law remedy for tortious wrong bottomed upon breach of a legally implied, rather than a contractually created, warranty of fitness." 40 The court simply pointed out that the state had long before abolished the privity requirement ${ }^{41}$ and illustrated with a few examples the absence of any logical reason to distinguish the bystander from the user or consumer. ${ }^{42}$ Here was a case where the court, which had not yet explicitly adopted strict tort liability but which now desired to hold for the bystander, sustained an implied warranty claim on tort principles.

Mitchell $v$. Miller ${ }^{43}$ involved the unusual fact situation of a parked auto that rolled downhill onto a golf course and struck plaintiff's de-

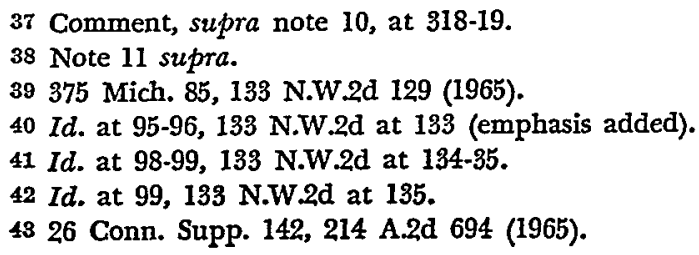


cedent. Again the action was in implied warranty and, as in Piercefield, a Connecticut court based its decision on tort principles, taking note of the trend allowing non-buyers a cause of action in strict tort rather than resorting to the fictions of implied warranty. ${ }^{44}$ The court reasoned that " $[t]$ here seems to be no sound public policy to bar a trial upon the issues raised in the complaint." 45 A third case, Toombs v. Fort Pierce Gas Co., ${ }^{46}$ held in favor of bystanders injured by a propane tank explosion on the limited ground that they were foreseeable plaintiffs who came within the "dangerous instrumentality" exception to Florida's implied warranty privity requirement.

Perhaps the most influential bystander case has been Elmore $v$. American Motors Corp., ${ }^{47}$ decided in 1969 by the Supreme Court of California. An occupant of an auto was injured when the drive shaft of defendant's car dropped to the pavement, causing it to swerve into plaintiff's lane. Plaintiff's subsequent action in strict tort liability was non-suited. On appeal, the high court reversed, citing the Restatement, Piercefield, Mitchell, and cases holding for other plaintiffs who were neither purchasers nor users. ${ }^{48}$ The court then stated four points which together constitute the clearest and most comprehensive judicial analysis of bystander recovery to date: (1) The public policy rationale underlying strict tort liability as announced in Greenman is equally applicable in bystander cases; ${ }^{49}$ (2) since strict tort liability applies even in the face of attempted disclaimer, the doctrine may not be limited on the theory that no representation of safety is made to the bystander; $;^{50}$ (3) injury to a bystander is often foreseeable by the manufacturer and restriction on bystander recovery is but a vestige of the disappearing privity requirement; ${ }^{51}$ and (4) bystanders should receive greater protection than consumers and users, who may inspect for defects and purchase selectively. ${ }^{52}$ But even the California Supreme Court apparently was unimpressed with the significance of bystander recovery

44 Id. at 148-50, 214 A.2d at 698 .

45 Id. at $150,214 \mathrm{~A} .2 \mathrm{~d}$ at 699 .

46208 So. 2d 615 (Fla. 1968).

4770 Cal. 2d 578, 451 P.2d 84, 75 Cal. Rptr. 652 (1969).

48 Id. at 585, 451 P.2d at 88, 75 Cal. Rptr. at 656.

49 Id. at 585-86, $451 \mathrm{P} .2 \mathrm{~d}$ at 88-89, 75 Cal. Rptr. at 656-57.

$50 I d ., 451 \mathrm{P} .2 \mathrm{~d}$ at $88,75 \mathrm{Cal}$. Rptr. at 657 .

51 Id. at 586, 451 P.2d at 89,75 Cal. Rptr. at 657.

52 Id. Though the bystanders in other cases were suing retailers and wholesalers as well as manufacturers, Elmore was the first case in which the court showed some reluctance to allow an action against the retailer. The court concluded, however, that the retailer's liability was desirable since it would afford the plaintiff maximum protection and since the retailer could adjust the cost of liability with the manufacturer. Id. at 587, 451 P.2d at 89,75 Cal. Rptr. at 657 . 
-the whole issue was disposed of in less than a third of the Elmore opinion.

Elmore was the first of a procession of cases holding for the bystander explicitly in strict tort without retention of the warranty label. Darryl v. Ford Motor Co. ${ }^{53}$ held the manufacturer of a truck with defective brakes strictly liable in tort to injured plaintiffs whose car it had struck. The Supreme Court of Texas said little more than that " $t]$ here is no adequate rationale or theoretical explanation why non-users and nonconsumers should be denied recovery against the manufacturer of a defective product." ${ }^{54}$ In Sills $v$. Massey-Ferguson, Inc. ${ }^{55}$ a federal district court anticipated Indiana law and allowed a strict tort claim by a bystander injured when a lawnmower threw a bolt. The court set up alternative theories of products liability: recovery could be had only if the injury was foreseeable, or the manufacturer could be liable to all persons. Without deciding which theory was proper, the court concluded that the bystander could recover under either. ${ }^{56}$ In Caruth $v$. Mariani ${ }^{57}$ an Arizona court allowed a cause of action to bystanders injured when the defective brakes of another auto caused a rear-end collision. The court found it sufficient to note the state's adoption of strict tort liability and the nationwide trend expanding it to the bystander ${ }^{58}$ and then merely paraphrased the Elmore reasoning. ${ }^{59}$ In Wasik $v$. Borg, ${ }^{60}$ another rear-end collision case, the Court of Appeals for the Second Circuit anticipated not only Vermont's adoption of strict tort liability, but its extension to bystanders as well. The court cited as authority the state courts' abandonment of privity and the legislature's adoption of a liberal variation of a Uniform Commercial Code provision allowing bystander recovery. ${ }^{61}$ A number of other cases have allowed a cause of action to persons who cannot be considered true bystanders because of some relationship with the owner or user of the product. $^{62}$

53440 S.W.2d 630 (Tex. 1969).

54 Id. at 633.

55 296 F. Supp. 776 (N.D. Ind. 1969) (anticipating Indiana law).

56 Id. at 781.

5711 Ariz. App. 188, 463 P.2d 83 (1970).

$58 \mathrm{Id}$. at $189-90,463 \mathrm{P} .2 \mathrm{~d}$ at $84-85$.

$59 \mathrm{Id}$. at 190-92, $463 \mathrm{P} .2 \mathrm{~d}$ at $85-87$. In Caruth, as in Elmore, objections to the retailer's liability were raised and disposed of. $I d$. at 191-92, $463 \mathrm{P} .2 \mathrm{~d}$ at 86-87.

60423 F.2d 44 (2d Cir. 1970) (anticipating Vermont law).

$61 \mathrm{Id}$. at $48-49$ (UNIForm Commercial Code $\$ 2-318$, Alternative $B$ ).

In addition to these cases, the Supreme Court of Missouri has recently taken a favorable albeit uncommitted stance toward bystander recovery in Katz v. Slade, 2 CCH PRoD. LIAB. REP. If 6473, at 10,269-70 (1970) (dictum).

62 Most of these cases involved injuries to employees from products being used in the vicinity of their activities. Speed Fasteners, Inc. v. Newsom, 382 F.2d 395 (10th Gir. 
The implication of these developments is clear. The ease with which the courts were able to allow bystander recovery is evidence that extension to the bystander was a foregone conclusion of the transition from implied warranty to strict tort liability. The bystander cases fall into two major patterns. In Piercefield and Mitchell the courts used tort principles to allow bystander recovery on "warranty" claims. Elmore, Darryl, Sills, and Caruth allowed bystander recovery under previously adopted strict tort liability, and Wasik adopted strict tort liability and extended it to the bystander simultaneously. Thus, most of the decisions for the bystander are based on an explicit tort theory. Those decisions preserving the warranty label tend to use tort principles. ${ }^{03}$ Moreover, with but one exception no jurisdiction which has adopted strict tort liability has rejected the bystander's claim. ${ }^{64}$

\section{Policy Considerations}

\section{A. Loss Spreading}

The public policy consideration now most widely accepted by courts $^{05}$ as the primary justification for strict products liability is loss

1967) (construing Oklahoma law) (carpenter injured by shank from fellow employee's stud gun allowed to sue manufacturer in implied warranty); Pike v. Frank G. Hough Co., 2 Cal. 3d 465, 467 P.2d 229, 85 Cal. Rptr. 629 (1970) (survivors of employee killed when paydozer backed over him without warning allowed recovery in strict tort); Johnson v. Standard Brands Paint Co., 274 Cal. App. 2d 331, 79 Cal. Rptr. 194 (1969) (survivors of worker killed by falling ladder allowed recovery in strict tort); Ford Motor Co. v. Cockrell, 211 So. $2 d 833$ (Miss. 1968) (workman pinned by truck whose starter engaged spontaneously allowed to sue manufacturer in strict tort); Lonzrick v. Republic Steel Corp., 6 Ohio St. 2d 227, 218 N.E.2d 185 (1966) (construction worker injured by falling steel joists allowed to sue manufacturer in strict tort). Some involved injuries to workers from products they were servicing. Klimas v. Int'l Tel. \& Tel. Corp., 297 F. Supp. 937 (D.R.I. 1969) (construing Rhode Island law) (electrician blinded when glass fuse exploded allowed to sue manufacturer in strict tort); Connolly v. Hagi, 24 Conn. Supp. 198, 188 A.2d 884 (1963) (gas station attendant injured by car that went into reverse allowed to sue manufacturer in implied warranty). Although in some of these cases the courts characterized the plaintiff as a user and in some his status was ambiguous, several have been cited as precedent for bystander recovery. E.g., Elmore v. American Motors Corp., 70 Cal. 2d 578, 585, 451 P.2d 84, 88, 75 Cal. Rptr. 652, 656 (1969).

63 Of the fifteen favorable bystander and bystander-type cases described at notes 39-62 supra, only three were decided on an implied warranty basis without explicit reliance on tort principles. Not surprisingly, the courts' logic in these cases was strained. Toombs, as indicated, rested on an arbitrary exception to the privity requirement. In Connolly, the court resorted to finding that the attendant had relied on the manufacturer's advertising and categorized him as an "ultimate consumer." 24 Conn. Supp. at 202, 206, 188 A.2d at 886,888 . The court in Speed Fasteners found for the plaintiff by saying that he stood "in the shoes of his employer." 382 F.2d at 398.

64 Of the eleven recent cases holding against the bystander cited in Note, supra note I1, at 916 n.s, and note 12 supra, only Davidson v. Leadingham, 294 F. Supp. 155 (E.D. Ky. 1968), involved a state that had adopted strict tort liability-and that decision was rendered by a cautious federal court construing Kentucky law in a diversity case.

c5 Keeton, Products Liability-Some Observations About Allocation of Rishs, 64 
spreading. ${ }^{66}$ This principle shifts losses caused by defective products ultimately to the manufacturer ${ }^{67}$ because he is assumed to be best able to minimize the economic impact of a loss by spreading it over a large number of persons. The manufacturer either absorbs the loss or insures against it, in either case spreading the additional cost among all purchasers of his product through higher prices; the purchaser buys not only the product, but also an insurance policy covering losses resulting from product defects. ${ }^{68}$

The loss spreading justification for strict products liability has been criticized on several counts. First, it is argued that in some cases the retailer or some other party may have greater spreading ability than the manufacturer. ${ }^{69}$ The plaintiff, however, may sue any seller and will normally choose the largest defendant, who is usually also the best

Mich. L. Rev. 1329, 1333 (1966); contra, Prosser, supra note 32, at 800. To the extent that the courts since Prosser's article have followed Greenman and the Restatement, see notes 27 supra and 66 infra, they appear to have shifted their emphasis to the loss spreading consideration.

66 In the products liability area, the principle was suggested in K. LrEWELLYN, supra note 15, at 341, and popularized by Traynor in Escola v. Coca Cola Bottling Co., 24 Cal. 2d 453, 461, 462, 150 P.2d 436, 440, 440-41 (1944) (concurring opinion). Commentators approved. E.g., R. Dickerson, supra note 17, at 86-89, 135-39, 277-79; James, General Products-Should Manufacturers Be Liable Without Negligence? 24 TENN. L. REv. 923 (1957); Noel, supra note 17, at 1010, 1017; Prosser, supra note 4, at 1120; cf. Calabresi, Some Thoughts on Risk Distribution and the Law of Torts, 70 YALE L.J. 499 (196I). The loss spreading principle was mentioned in Henningsen v. Bloomfield Motors, Inc., 32 N.J. 358, 379, 161 A.2d 69, 81 (1960), and was adopted in Greenman v. Yuba Power Products, Inc., 59 Cal. 2d 57, 63, 377 P.2d 897, 901, 27 Cal. Rptr. 697, 701 (1962) (Traynor, C.J.), in REstatement (SECOND) OF TORTS $\$ 402 \mathrm{~A}$, comment $c$, and in the subsequent case law, see notes 27 and 65 supra.

B7 Although any seller-manufacturer, wholesaler, or retailer-may be held strictly liable in tort for such losses, REsTATEMENT (SECOND) OF TORTs § 402A, comment $f$, obviously the manufacturer whether or not he is the initial defendant ultimately may be held liable.

68 The classic statement is that in Escola v. Coca Cola Bottling Co., 24 Cal. 2d 453, 461, 462, 150 P.2d 436, 440, 440-41 (1944) (Traynor, J., concurring). Calabresi distinguishes between ability to insure or self-insure, on the one hand, and ability to pass part of the loss on to purchasers or to production factors such as labor or capital, on the other hand, as two separate ways of spreading losses. G. CALABresI, THE Costs of AccidenTs-A LEGAL AND ECoNomic ANALYsis 50-51 (1970). The typical manufacturer probably employs both, insuring against products liability and then passing the cost of insurance on to purchasers.

A variation on the concept of loss spreading is loss bearing or the "deep pocket" doctrine, which holds that losses should be shifted to the manufacturer solely because he is best able to bear them, regardless of insuring or spreading ability. The distinction is well made in $i d$. at $40-42$.

69 Peairs, The God in the Machine, 29 B.U.L. Rev. 37, 76-77 (1949); Plant, Strict Liability of Manufacturers for Injuries Caused by Defects in Products-An Opposing View, 24 TENN. L. REv. 938, 947 (1957); Smyser, Products Liability and the American Law Institute: A Petition for Rehearing, 42 U. DET. L.J. 343, 349-50 (1965); see Kessler, supra note 23, at 934-37. 
spreader; beyond that, sellers within the chain of distribution may arrive at indemnity and price agreements consistent with their loss spreading abilities. ${ }^{70}$ Another criticism is that, where consumer demand for the product is elastic, price increases sufficient to offset liability will result in decreased production and denial of the product to some consumers-especially the poor. ${ }^{71}$ It is arguably unfair to force all consumers to pay the increased price when some may wish to purchase "uninsured" products at lower prices while those who desire insurance may purchase it privately. ${ }^{72}$ Since strict liability does not, however, substantially increase the manufacturer's liability over that imposed under res ipsa loquitur, prices are not significantly affected and denial of the product to consumers is minimal. ${ }^{73}$ As to free choice, if purchasers had adequate knowledge of product risks and did not so consistently ignore the possibilities of injury, they would probably choose the insured product. ${ }^{74}$ It has been suggested also that the negligence action under the res ipsa loquitur doctrine provides adequate loss spreading without strict liability. However, negligence liability is deficient because uncertainty about trial outcome tends to reduce settlement amounts. ${ }^{75}$ Finally, some academics observe that social insurance would be a better means of spreading losses and could deal with misfortunes other than accident losses. ${ }^{76}$ In the absence of social insurance, however, strict liability remains the most efficient means to spread losses. Moreover, strict liability may have a deterrent effect on manufacturers' conduct, while social insurance would involve no deterrence and would increase accident costs. ${ }^{77}$

Despite the uncertainty pervading these arguments, ${ }^{78}$ courts do apply the loss spreading principle, and this further explains the ease with which courts have been able to extend strict products liability to the

70 R. Dickerson, supra note 17, at 277-79; James, supra note 67, at 925.

71 Plant, supra note 69, at 946-47; cf. Buchanan, In Defense of Caveat Emptor, $38 \mathrm{U}$. CHI. L. REV. 64 (1970); McKean, supra note 23, at 50.

72 W. Blum \& H. Kalven, Jro, Public Law Perspectives on a Private law Problemaauto Compensation Plans 59 (1964).

73 R. Dickerson, supra note 17 , at 262.

74 Cf. Calabresi \& Bass, Right Approach, Wrong Implications: A Critique of McKean on Products Liability, 38 U. CHI. L. REv. 74, 88-89 (1970); Dorfman, The Economics of Products Liability: A Reaction to McKean, 38 U. CHr. L. REv. 92, 98-102 (1970).

75 Prosser, supra note 4, at 1116.

76 Peairs, supra note 69, at 77; Plant, supra note 69, at 947-48.

77 G. G. GaLABREst, supra note 68 , at $43-44$.

78 Since the arguments on both sides proceed from hypothesis and theory and not empirical economic research, there is no certain choice between them. Posner, Book Review, 37 U. Chr. L. Rev. 636, 646-48 (1970). We must often base choices on our intuitions, however; in products liability our intuitions have weighed in favor of strict liability. Gilmore, Products Liability: A Commentary, 38 U. CHI. L. Rev. 103 (1970). 
bystander. To the extent that the loss spreading arguments support strict products liability to the user or consumer, they apply equally to bystander recovery. As the court recognized in Caruth v. Mariani: ${ }^{79}$

The public policy is to protect "injured persons" and not just "users and consumers."

We choose to protect the member of the public since those involved in the chain of marketing can distribute the risk between themselves by means of insurance and other indemnity agreements. They should be better equipped economically to do so than some innocent member of the public. $^{80}$

Simply put, the bystander is in the same position vis a vis the manufacturer as the user or consumer; therefore, the bystander's loss also should be shifted to the manufacturer. The court in Sills $v$. MasseyFerguson, Inc. ${ }^{81}$ reasoned that "the manufacturer is better able to bear the loss than is the injured person" and that "bystanders as a class would not generally be better able to bear the loss than users or consumers." 82

Moreover, bystanders are probably even more in need of the insurance provided by loss spreading than users or consumers. The latter, as Elmore v. American Motors Corp..$^{83}$ pointed out, "have the opportunity to inspect for defects and to limit their purchases to articles manufactured by reputable manufacturers and sold by reputable retailers, whereas the bystander ordinarily has no such opportunities."84 Furthermore, the bystander is less likely than the user or consumer to insure privately-he does not use the product and is therefore more likely to undervalue or ignore the risk of injury associated with it. ${ }^{85}$

One adverse distinction is possible. Because the bystander does not purchase the product he is not part of the pool of persons among whom losses are spread; he seems to get a free ride for which consumers of the product are forced to pay. However, the objection is diminished when products and consumers are considered in the aggregate. Bystanders as a class purchase most of the same products to which they are exposed as bystanders. Thus as a class they indirectly subsidize the

7911 Ariz. App. 188, 463 P.2d 83 (1970).

80 Id. at 191, 192, $463 \mathrm{P} .2 \mathrm{~d}$ at 86,87 .

81296 F. Supp. 776 (N.D. Ind. 1969) (anticipating Indiana law).

82 Id. at 781 .

8370 Cal. 2d 578, 451 P.2d 84, 75 Cal. Rptr. 652 (1969).

$84 I d$. at 586, 451 P.2d at 89, 75 Cal. Rptr. at 657.

85 Note, supra note 11, at 935 . 
manufacturer's liability and in this sense do pay for the insurance policy tied to the product.

\section{B. Deterrence}

A second suggested public policy justification for strict products liability is deterrence. ${ }^{80}$ Under the simplest formulation, losses caused by defective products ultimately are shifted to the manufacturer in order to deter him from marketing such products. ${ }^{87}$ However, when one considers that many product defects sufficient to impose liability do not result from reasonably avoidable conduct on the part of the manufacturer, the principle as stated loses some of its force. The courts, perhaps sensitive to this point, have begun to subordinate deterrence to loss spreading as the primary consideration supporting strict products liability. 88

Recently, legal economists have further developed and articulated the basic notion of deterrence into a more sophisticated policy consideration, sometimes described as economic efficiency, ${ }^{89}$ which at least in the literature threatens to displace loss spreading as the primary test for the validity of strict products liability. Under this formulation, Iosses caused by defective products are placed upon the party who by changing his activity - that is, by making safer products or by using

86 In the products liability area, simple deterrence probably first emerged as a policy consideration in warranty and negligence cases. It is favorably mentioned in the commentary. E.g., R. Dickerson, supra note 17, at 86-89, 135-39, 261-62, 277-79; K. LLEWELIYN, supra note 15, at 341; James, supra note 66; Noel, supra note 17, at 1009, 1011, 1017. It was cited in support of strict products liability in Escola v. Coca Cola Bottling Co., 24 Cal. 2d 453, 461, 462, 150 P.2d 436, 440, 440-41 (1944) (Traynor, J., concurring), in Henningsen v. Bloomfield Motors, Inc., 32 N.J. 358, 379, 161 A.2d 69, 81 (1960), in RESTATEMENT (SECOND) OF TORTs $\S 402 \mathrm{~A}$, comment $c$, and in the subsequent case law, Prosser, supra note 32 , at 799. But see note 65 supra.

87 For a concise statement of the principle, see Escola v. Coca Cola Bottling Co., 24 Cal. 2d 453, 461, 462, 150 P.2d 436, 440, 440-41 (1944) (Traynor, J., concurring).

88 Note 65 supra.

89 This principle has its basis in the general theorem stated in Coase, The Problem of Social Cost, $3 \mathrm{~J}$. LAw \& EcoN. 1 (1960), restated in terms of products liability in note 90 infra. Its general development can be traced through Demsetz, The Exchange and Enforcement of Property Rights, 7 J. LAw \& EcoN. 11 (1964); Calabresi, Transaction Costs, Resource Allocation and Liability Rules-A Comment, 11 J. LAw \& EcoN. 67 (1968); Calabresi, Does the Fault System Optimally Control Primary Accident Costs? 33 LAw \& Contenr. Prob. 429 (1968); Nutter, The Coase Theorem on Social Cost: A Footnote, 11 J. LAw \& Econ. 503 (1968); G. CALABresi, supra note 68. Another line of development focused on no-fault auto compensation plans. W. BLUM \& H. KALVEN, JR., supra note 72, at 54-65; Calabresi, Fault, Accidents and the Wonderful World of Blum and Kalven, 75 YALE L.J. 216, 222-33 (1965); Calabresi, Views and Overviews, 1967 U. ILL. L.F. 600, 603-11; Blum \& Kalven, The Empty Cabinet of Dr. Calabresi: Auto Accidents and General Deterrence, 34 U. CHI. L. REv. 239, 244-64 (1967). Only recently has economic efficiency been applied specifically to products liability. Symposium-Products Liability: Economic Analysis and the Law, 38 U. CHr. L. REv. 1 (1970). 
products more carefully-can most cheaply reduce the sum of accident costs and the costs of avoiding accidents. ${ }^{90}$ Most proponents of the economic efficiency approach claim that it supports leaving the loss with the consumer, at least where the manufacturer is not negligent.91 Calabresi, however, suggests that economic efficiency does support strict products liability. ${ }^{22}$

Opponents of strict liability assert that negligence liability and market pressures already provide strong incentives for the manufacturer to make reasonably safe products. ${ }^{93}$ It is further claimed that the manufacturer's efforts to comply with the strict liability standard will substantially increase production costs, while the consumer can easily take extra precautions when using the product-making the consumer the party who can most cheaply avoid accident costs.94 However, negligence liability and market pressures may be inadequate to induce invention of new techniques to make products safer. A negligence standard would not impose liability for defective products that meet existing norms, ${ }^{95}$ and the market is generally unresponsive to changes in product safety. ${ }^{96}$ More important, even if liability were placed upon consumers because they were thought to be the class able to avoid accident costs most cheaply, they might "externalize" the

90 If both manufacturers and consumers had perfect information about risks and there were no transaction costs involved in bargaining between them, then (barring coercion and interference) it would not matter from the standpoint of economic efficiency which party initially bore losses caused by defective products. If consumers were made liable they would-depending on which was cheaper-either take greater precautions in the use of products or pay manufacturers higher prices for safer products, while if manufacturers were made liable they would similarly either make safer products or charge lower prices to consumers who took precautions; in either case, optimum allocation of resources would be achieved and accident costs would be optimized. Since information and transaction costs are high, however, accident cost optimization cannot be achieved unless liability is correctly placed upon the party for whom it is cheapest to avoid accident costs; if the wrong party were made liable, information and transaction costs would often make it not worthwhile for him to "bribe" the other party to avoid accident costs. Cf. Coase, supra note 89.

91 Buchanan, supra note 71; McKean, supra note 23, at 24-56.

92 Calabresi \& Bass, supra note 74, at 76-89; see Dorfman, stupra note 74.

Unlike loss spreading and simple deterrence, economic efficiency has not been cited in judicial opinions as a policy consideration supporting strict products liability. While it is thus unlikely that it played a direct role in support of strict products liability to the user or consumer, quite possibly some judges harbored rough ideas and intuitions of economic efficiency which were of some influence.

93 Leidy, Another New Tort? 38 Mrch. L. Rev. 964, 987 (1940); McKean, supra note 23, at 44-45, 50; Plant, supra note 69, at 945; Smyser, supra note 69, at 348. Prosser also doubts whether strict liability increases deterrence. Prosser, supra note 4, at 1119, 1122.

94 Buchanan, supra note 71, at 67-70, 72; McKean, supra note 23, at 42-50.

95 R. Dickerson, supra note 17, at 261; James, supra note 67, at 923; Noel, supra note 17, at 1011-12.

96 Note 75 supra. 
deterrent effect of this liability either through undervaluation of risks involved in product usage or through general accident insurance. Consequently, consumers would in fact be less likely to alter their behavior than the manufacturer, who is better able to value risks and whose products liability insurance premiums more accurately reflect his accident rate. ${ }^{97}$ Another criticism of the deterrence rationale is that the cost of making products safer will result in denial of the product to some consumers. Again, it is arguably unfair to force consumers to pay an increased price instead of purchasing more dangerous products at lower prices and using them more carefully. ${ }^{98}$ However, if consumers had sufficient information to value risks properly, they would probably choose the safer product. ${ }^{29}$

As was the case with loss spreading, to the extent that the policy arguments support user or consumer recovery, ${ }^{100}$ the case for the bystander is equally strong. Clearly the bystander is no better able than the user or consumer to avoid injury from product defects. As the court in Piercefield v. Remington Arms Co. ${ }^{101}$ noted in holding for the bystander, "[T] $]$ he manufacturer is best able to control dangers arising from defects of manufacture . . ."102 Darryl v. Ford Motor Co. ${ }^{103}$ flatly stated that "[t]he reason for extending the strict liability doctrine to innocent bystanders is the desire to minimize risks of per-

97 Calabresi \& Bass, supra note 74, at 88-89.

98 Buchanan, supra note 71; McKean, supra note 23, at 51 .

99 Note 74 supra. Also, it is pointed out that transaction costs under manufacturer liability are higher than under user and consumer liability; thus consumers can bribe manufacturers to make products safer more easily than manufacturers can bribe consumers to use products more carefully. McKean, supra note 23 , at $44,49,50$. But this makes a difference only if it is uncertain who is the cheapest accident cost avoider. Calabresi \& Bass, supra note 74 , at 81 .

At this point the relationship between loss spreading and deterrence should be noted more fully. Although the two policy considerations are often cited together, e.g., $\mathbf{R}$. DICKRRSON, supra note 17 , at 135; K. LLEWELIYN, supra note 15 , at 341 , to some extent they are competing objectives, $i d$. at 138; e.g., text at note 77 supra. Commentators differ as to which to accord more weight. Compare McKean, supra note 23, at 5-6, 56-63, with Calabresi \& Bass, supra note 74, at 75-76. In Calabresi's general theoretical framework, three types of accident costs are quantifiable: the primary cost of the accident to its victim in terms of personal injury and other loss, the secondary cost of economic dislocation resulting from failure to compensate the victim, and the tertiary cost of judicial and administrative processes designed to reduce primary and secondary costs. (Except for the argument that victims should be made liable, the last is not relevant to the strict liability arguments since roughly the same amount of litigation should occur whether its object is to determine negligence or defectiveness. But see McKean, supra note 23, at 50.) Calabresi would weigh all three costs together in order to make a liability decision. G. CALABREsI, supra note 68.

100 See note 78 supra.

101375 Mich. 85, 133 N.W.2d 129 (1965).

$102 \mathrm{Id}$. at 98,133 N.W.2d at 184 .

103440 S.W.2d 630 (Tex. 1969). 
sonal injury and/or property damage."104 In Mitchell v. Miller ${ }^{105}$ the court concluded that " $[t]$ he public policy which protects the consumer and user [from the likelihood of injury] should also protect the innocent bystander." 100

Indeed, the case for the bystander is actually more compelling than that for the user or consumer. As the Elmore court pointed out, since the bystander is not a purchaser or user it is impossible for him to exercise care in the selection or use of the product. ${ }^{107}$ Even if he could avoid dangers caused by products used by others-for example, wheels flying off passing cars-the cost of such super-vigilance probably would exceed the amount of accident costs avoided. It is more likely that bystanders would simply ignore these risks entirely, since they relate to products they do not use. ${ }^{108}$

Furthermore, since by definition the bystander is not a participant in the relevant commercial transaction, he cannot exert market pressure upon the manufacturer to make safer products. And the transaction costs involved in any form of non-market pressure on the manufacturer would be prohibitive; indeed, it is absurd to think bystanders would organize and negotiate with manufacturers or users in order to bribe them to exercise more care. ${ }^{109}$ Even those commentators who prefer some type of fault system for user and consumer recovery acknowledge the support of economic efficiency for strict products liability to the bystander. As McKean has noted:

With user liability it is expensive-as it would be with victim or producer liability-for potential bystander victims to get together and bid for safer products .... In fact, I can visualize no arrangement that would greatly reduce transaction costs for third parties [bystanders] in bargaining for what they prefer. ${ }^{110}$

104 Id. at 633.

10526 Conn. Supp. 142, 214 A.2d 694 (1965).

106 Id. at 150, $214 \mathrm{~A} .2 \mathrm{~d}$ at 699.

107 Note 84 supra and accompanying text.

108 Note 85 supra and accompanying text.

109 Calabresi \& Bass, supra note 74, at 77.

110 McKean, supra note 23, at 47. A proponent of caveat emptor has admitted:

The standard models [of products liability] concentrate on contractual arrangements between buyers and sellers, and they must be amended to take into account the potential interests of third parties. If it can be argued that, as product technology has developed, products increasingly exert effects on third parties in the event of accident, a plausible case can be made for the shift away from caveat emplor.

Buchanan, supra note 71 , at 70 . Buchanan suggests, however, that strict liability should apply only to products that are likely to affect bystanders. Id. at 71. It is ironic to note that under Buchanan's suggestion the product area perhaps least worthy of strict liability is the area in which it was first adopted-food; except for exploding bottles of carbonated beverage, food involves little risk of bystander injury. Note, supra note 11, at 933. 
The essential point is that, since transaction costs are prohibitive for the bystander, the law should allow him recovery in strict products liability no matter how it treats the user or consumer.

\section{Possibility of Further Extension}

Bystander recovery extends strict products liability beyond the chain of distribution to one who has no connection with the product save that it injured him. This raises the question: What is so special about products? Why are all losses caused by physical defects in goods shifted to manufacturers, while losses caused by imperfect performance of services are shifted only upon proof of negligence? ${ }^{111}$ Indeed, why not hold any enterprise strictly liable for any harm causally related to its acts or omissions, so long as it fulfills the policy criteria of being best able to spread losses and reduce accident costs?112

The problem of extension beyond the product must have been clear to at least some of the courts that have allowed bystander recovery. The Supreme Court of California, for example, has set important precedent in the products liability area for more than a quarter of a century. Yet Traynor decisions against injured victims of non-negligent department stores co-exist with his decisions for injured victims of non-negligent manufacturers, and no attempt is made to reconcile the apparent inconsistency. ${ }^{113}$ Why have the courts not spoken to the problem?

One possible reason is that those courts which perceive the dichotomy

111 Some movement toward such an extension has already been made. Many courts have abandoned the strict products liability requirement of a sale, Farnsworth, Implied Warranties of Quality in Non-Sales Cases, 57 CoLvim. L. REv. 653 (1957), and have extended strict tort liability to cases involving bailments and leases, 1 CCH Prod. Liab. REP. I 4170. Nor must the defective "product" be a chattel; strict tort liability has been imposed on builders for defects in real estate. E.g., Schipper v. Levitt \& Sons, Inc., 44 N.J. 70, 207 A.2d 314 (1965).

112 "Enterprise liability" is by no means a new suggestion. Several commentators have proposed that enterprises of all kinds be held strictly liable for losses causally related to their activities-whether or not in connection with a defective product or an imperfectly performed service-so long as they fulfill certain policy criteria. E.g., A. EHRENZwEIG, NEGLigENCE WrrHout FaUtr (1951); Calabresi, supra note 66; Keeton, Conditional Fault in the Law of Torts, 72 HARv. L. REv. 401 (1959); Morris, Hazardous Enterprises and Risk-Bearing Capacity, 61 YALE L.J. 1172 (1952). Enterprise liability would extend recovery to a broader class of victims than products and service liability combined, even with bystander recovery under both. See Plant, supra note 69, at 946; Prosser, The Fall of the Citadel, supra note 11 , at 800 n.65. The policy reasons that support service liability may well support enterprise liability with equal force. Nonetheless, since service liability is presently the easiest and most obvious extension of strict liability for the courts to make, it will be the focus of the ensuing discussion.

Another possible but less creditable extension of liability, to product-related losses in the absence of defectiveness, is beyond the scope of this comment.

113 Kalven, Torts: The Quest for Appropriate Standards, 53 CanIf. L. REv. 189, 201-06 (1965). 
between products and services view it as a real and difficult problem which they do not want to face. It is more likely, however, that the courts do not view service liability as a real possibility. Apparently, no injured customers have yet sued suppliers of services on a theory of strict tort liability. Moreover, the policy considerations which compelled extension of strict products liability to the bystander may not support service liability with equal force, if at all.

Public pressure has long been confined to the product. From the muckraking of Upton Sinclair ${ }^{114}$ through the enactment of federal and state legislation ${ }^{115}$ we have come full circle to the crusades of Ralph Nader ${ }^{116}$ today, and never have we strayed with strict liability into the service area. The public ire is aroused more by disclosures of unwholesome food and uncrashworthy automobiles than by reports of escalator mishaps in department stores or bad weather air accidents. There is no guarantee, however, that this will always be the case. Public pressure already has helped achieve in another area, workmen's compensation, the strict liability of enterprises to one class of victims, employees. ${ }^{117}$ In any event, a court faced with an argument for service liability must have a better reason than absence of public pressure if it is to differentiate services from products. Prosser's only stated reason for hesitating to advocate immediate extension of strict products liability to the bystander-that the pressure on the courts was a consumer pressure ${ }^{118}$ did not hold up for very long.

The primary reason for denying extension of strict liability beyond the product must be that the product is in fact different. Only if policy considerations demand special treatment of the product will a legal framework that limits strict liability to the product be logically satisfying and historically stable.

Does loss spreading support service liability? While it is clear that there are many large service enterprises, ${ }^{119}$ it is equally clear that manu-

114 U. Sinclair, The Jungle (1905).

115 Much of this legislation is reprinted and discussed in P. KEETON \& M. SHAPO, supra note 11 .

116 E.g., R: NADER, UNSAFE AT ANY SPEed (1965).

117 Some commentators feel that a broad shift toward "enterprise liability" has been taking place in a number of other areas as well. E.g., A. EHRENZwEIG, supra note 112.

118 See note 11 supra. Compare Llewellyn's earlier observation regarding the food exception to the privity requirement:

The emotional drive and appeal of the cases centers in the stomach. ... But the development is not confined to this, its center. It spreads to cover other hazards to consumers.

K. LLEWELLYN, supra note 15 , at 342 .

119 Cf. Smyser, supra note 69, at 349. In Goldberg v. Kollsman Instrument Corp., 12 N.Y.2d 432, 191 N.E.2d 81, 240 N.Y.S.2d 592 (1963), an implied warranty action by the survivors of an airplane passenger killed in a crash caused by a defective altimeter, the 
facturers are generally better able to spread losses than suppliers of services. To establish a manufacturing operation of even modest size, a relatively large amount of capital investment is required. More important, the pool of buyers among whom losses are spread is likely to be large. In the service area, on the other hand, loss spreading ability varies widely-there are department stores but also corner groceries, major carriers but also self-employed cabbies. Moreover, in the product situation there is likely to be a greater overlap between the pool of potential victims and the pool of consumers to whom losses are spread..$^{120}$

It is just as doubtful whether deterrence supports extension to services. Losses should not be shifted unless the deterrent effect of potential liability reduces not only accident costs, but the sum of accident costs and accident avoidance costs. In the product situation, the effect of deterrence on accident costs, even if it has only a small effect on conduct, is great. Given mass production and mass marketing, a single error can result in a large number of injuries. In contrast, a single error made by a service enterprise is less likely to result in a large number of injuries. It may not recur as in the case of a mass produced product, and it is unlikely to affect a large group of people since the service enterprise usually deals with individuals or small groups. Moreover, an imperfectly performed service often may carry more warning to the potential victim than a latently defective product, ${ }^{121}$ making it relatively easy for the service customer to avoid accidents by taking precautions. Consequently, while imposition of strict liability might induce service enterprises to take relatively expensive precautions during performance of services, it would not be likely to reduce accidents substantially. To the extent that service liability would increase the sum of accident costs and accident avoidance costs, it is economically inefficient.

Even if these reasons for differentiating the product do not entirely dispose of the apparent inconsistency, the courts still may not be willing to extend strict tort liability to service enterprises. Tort law has tolerated other special areas of strict liability without allowing them to expand at the expense of broadly applicable negligence principles, for example ultrahazardous activities, nuisance, workmen's compensation, libel, misrepresentation, and respondeat superior. ${ }^{122}$ Strict products liability,

majority held the airplane manufacturer liable, declining to impose liability upon the manufacturer of the component part or the airline company. The dissent maintained that the loss spreading objective could best be achieved by imposing liability upon the airline. $I d$. at $440-43,191$ N.E.2d at $85-87,240$ N.Y.S.2d at 598-600. The case raises the question which defendant-the manufacturer or the service enterprise-should ultimately be held liable in the event of a service that was imperfect because it involved a defective product.

120 Kalven, supra note 118, at 205-06.

$121 \mathrm{Id}$. at 206.

122 Prosser, The Fall of the Citadel, supra note 11, at 802. 
given its separate evolution and at least some basis for differentiating the product, seems a likely candidate for similar special treatment, at least in the foreseeable future. ${ }^{123}$

Yet so much in the law depends upon fortuity. The first case in which a serious argument for service liability is made may involve a unique fact situation with sufficient emotional appeal to persuade the court to take a small step beyond the product. ${ }^{124}$ From such small steps, it should be abundantly clear, proceed long and arduous excursions of irreversible common law development.

123 Kalven; supra note 113, at 205.

124 "Strict liability as well as negligence is a part of our common law heritage and where its areas lend themselves to natural and easy extension, it is my thesis that the courts should make the extension." James, supra note 66 , at 924 . The stage is already set. The first such case might involve a service involving a product, as for example the repair of an automobile. The step would be an easy one to take. 